\title{
Pengembangan Laboratorium Terbang Berbasis UAV: Pemodelan Momen Inersia
}

\author{
Ony Arifianto*) \& Imam Safi'i \\ Fakultas Teknik Mesin dan Dirgantara, Institut Teknologi Bandung (ITB) \\ (cooresponding author) ony@ftmd.itb.ac.id ${ }^{\star}$ )
}

\begin{abstract}
Abstrak
Makalah ini membahas tentang pembuatan model matematika dari laboratorium terbang yang dikembangkan oleh FTMD-ITB. Laboratorium terbang ini merupakan pesawat udara nirawak bersayap tetap yang telah dilengkapi dengan instumentasi yang dibutuhkan untuk mendapatkan data untuk pengujian terbang. Pengujian terbang tersebut dilakukan untuk memperkaya pengajaran dalam kuliah-kuliah mekanika terbang. Model matematika yang dikembangkan nantinya akan digunakan untuk merancang sistem kendali otomatik untuk membantu operator dalam mendapatkan data uji terbang. Makalah akan secara khusus membahas tentang pemodelan momen inersia dari pesawat nirawak yang digunakan sebagai laboratorium terbang. Pemodelan momen inersia dilakukan dengan menggunakan uji bifilar pendulum. Untuk melihat apakah pengujian dapat memberikan hasil yang logis dan cukup akurat, uji validasi dilakukan terlebih dahulu dengan menggunakan balok kayu. Hasil momen inersia dari balok kayu kemudian dibandingkan dengan hasil dari perhitungan dengan menggunakan metode analitik. Baik uji bifilar pendulum pada balok kayu maupun laboratorium terbang menunjukkan hasil momen inersia yang relatif wajar untuk pesawat sekelasnya.

Kata Kunci: UAV, laboratorium terbang, momen inersia, bifilar pendulum
\end{abstract}

\section{Pendahuluan}

Program Studi Teknik Dirgantara, Institut Teknologi Bandung (ITB), saat ini tengah mengembangkan sebuah laboratorium terbang berbasis unmanned aerial vehicle (UAV) bersayap tetap. UAV yang digunakan dilengkapi dengan peralatan sensor, autopilot, data akuisisi, dan sistem telemetri. UAV juga dilengkapi dengan sebuah ground control station yang akan menerima, menampilkan, dan merekam data penerbangan. Laboratorium terbang ini akan digunakan sebagai bagian dari proses belajar-mengajar di Program Studi Teknik Dirgantara, utamanya dalam kuliah-kuliah mekanika terbang. Dengan adanya laboratorium terbang ini, mahasiswa dapat melakukan berbagai eksperimen, seperti uji kestabilan statik, uji drag ploar, dan uji kestabilan dinamik.

Pada pekerjaan sebelumnya [1][2][3], graphical user interface (GUI) untuk pengujian kestabilan statik longitudinal dan drag polar telah dikembangkan. Untuk melanjutkan pengembangan dari laboratorium terbang, selanjutnya perlu dikembangkan model matematika dari UAV yang digunakan, salah satunya model dari momen inersianya.

Terdapat dua pendekatan yang dapat digunakan untuk memperoleh model momen inersia, yakni dengan metode perhitungan analitik dan eksperimental. Pada metode perhitungan analitik, momen inersia dari UAV akan dihitung dengan menggunakan berat dan jarak dari masing-masing komponen penyusun UAV terhadap titik center of gravity (CG) dari UAV. Pemodelan momen inersia dengan menggunakan metode ini tidaklah praktis [4]. Hal ini dikarenakan cukup rumit untuk menentukan berat dan jarak dari masing-masing komponen relatif terhadap titik CG UAV secara akurat. Di lain sisi, metode eksperimen sudah terbukti sesuai untuk digunakan dalam pemodelan momen inersia pada UAV kecil [4]. Berbeda dengan metode perhitungan analitik yang cukup kompleks, metode eksperimen relatif lebih mudah untuk dilakukan.

Prosedur uji eksperimental untuk penentuan momen inersia dapat dibagi ke dalam dua kategori besar, yakni metode akselerasi dan osilasi [5]. Pada metode akselerasi, momen inersia diperoleh dari akselerasi rotasional objek pada sumbu yang diperlukan, sedangkan pada metode osilasi momen inersia diperoleh dari periode osilasi.

Berbagai pengujian momen inersia yang termasuk ke dalam metode osilasi itu sendiri dapat dipilah ke dalam dua bagian besar lagi berdasarkan gaya pemulih yang digunakan dalam pengujian. Ada pengujian yang menggunakan pegas atau peralatan elastis lainnya sebagai pemberi gaya pemulih, ada pula pengujian yang menggunakan gaya gravitasi sebagai gaya pemulih atau biasa disebut dengan metode pendulum. Referensi [6] mengklasifikasikan metode eksperimental yang dapat digunakan untuk mengestimasikan momen inersia dari suatu objek sebagai berikut. 


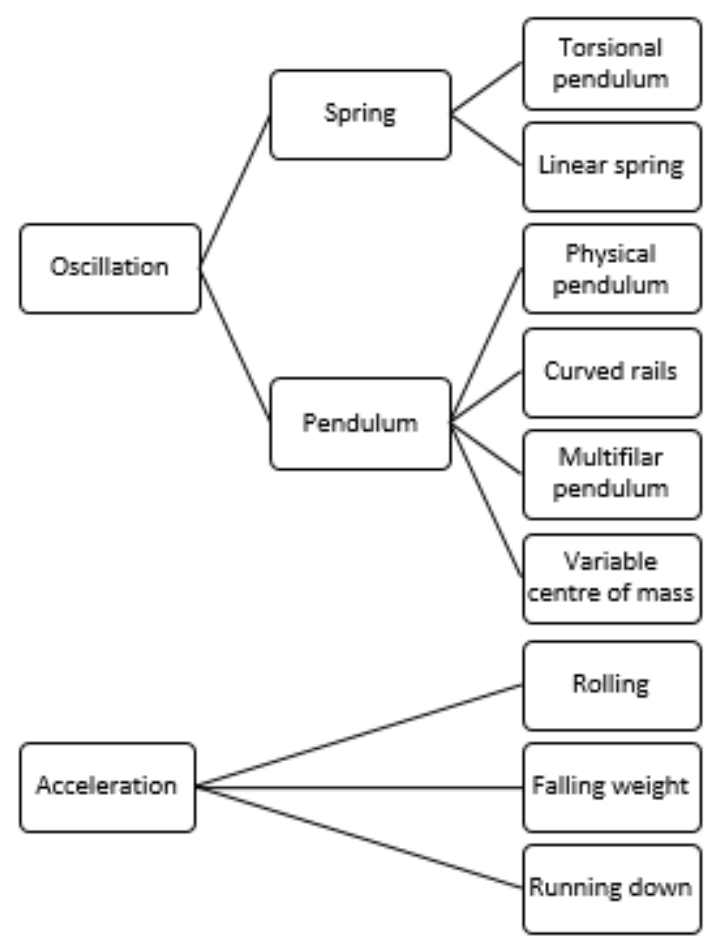

Gambar 1 klasifikasi metode eksperimental untuk pemodelan momen inersia

Salah satu metode pendulum yang biasa digunakan untuk memodelkan momen inersia dari suatu objek adalah bifilar pendulum. Makalah ini akan secara khusus membahas tentang pengembangan model momen inersia dari laboratorium terbang dengan uji bifilar pendulum. Bersama dengan model dari gaya aerodinamika dan sistem propulsi, model momen inersia yang diperoleh ini nantinya akan digunakan untuk merancang sistem kendali otomatik untuk membantu operator dalam mendapatkan data uji terbang.

\section{Model Laboratorium Terbang}

Model pesawat nirawak yang digunakan sebagai platform dasar dari laboratorium terbang adalah model pesawat glider bermesin bernama Sky Surfer 1400X8. UAV ini merupakan produk dari pabrikan pesawat model X-UAV. UAV ini memiliki bentang sayap sepanjang $1,4 \mathrm{~m}$, dengan panjang $0,915 \mathrm{~m}$.

Laboratorium terbang dilengkapi dengan berbagai macam peralatan sensor dan sistem autopilot sebagai payload. Berat keseluruhan dari pesawat beserta seluruh sistem yang ada di dalamnya adalah $0,73 \mathrm{~kg}$.

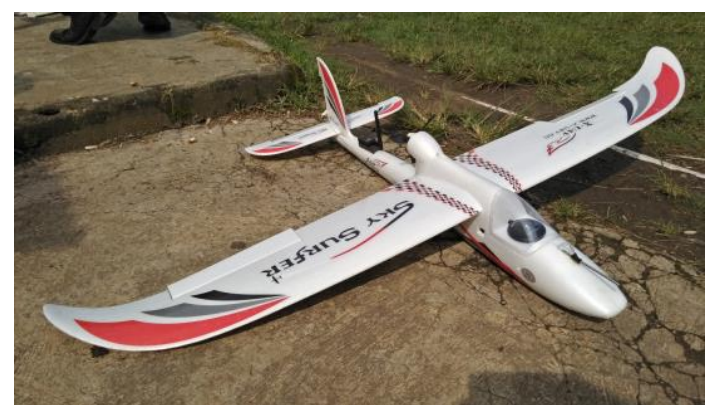

Gambar 2 pesawat Sky Surfer $1400 \times 8$ yang digunakan sebagai model laboratorium terbang

\section{Bifilar Pendulum}

Bifilar pendulum, sebagaimana yang nampak pada Gambar 3, adalah pendulum torsional yang terdiri dari sebuah objek yang digantung dengan menggunakan dua buah tali tipis dan paralel dengan panjang $L$ yang terpisah pada jarak $2 r$.
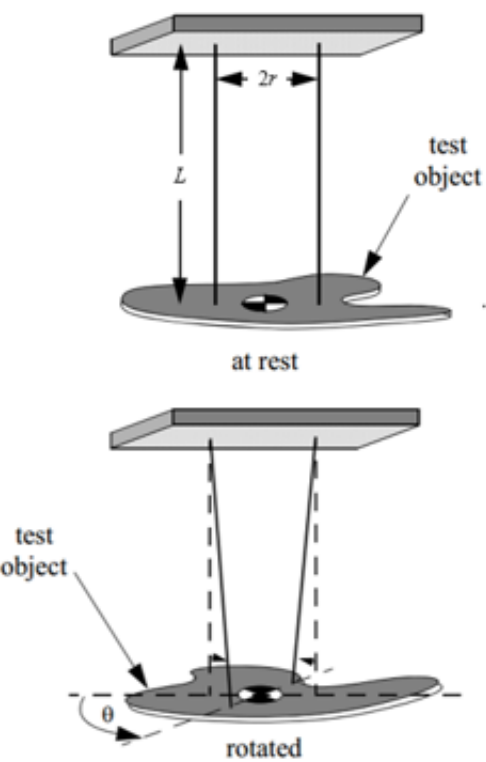

Gambar 3 skema uji bifilar pendulum [7]

Jika pendulum diberi simpangan dengan diputar pada bidang horizontal, maka tidak akan ada akselerasi pada arah sumbu vertikal. Jika kemudian pendulum dilepaskan, maka ia akan berosilasi sampai kembali ke posisi kesetimbangannya. Diagram benda bebas dari setengah bagian bifilar pendulum ketika berosilasi ditunjukkan pada Gambar 4 sebagai berikut. 


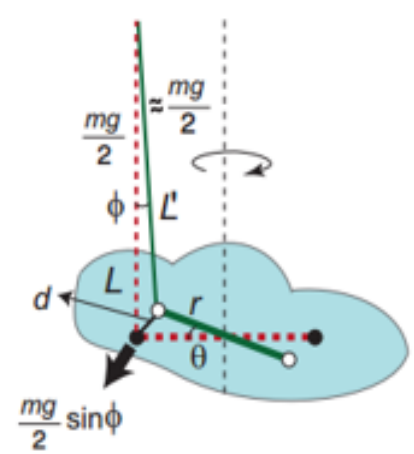

\section{Gambar 4 diagram benda bebas ketika bifilar pendulum berosilasi [8]}

Berdasarkan Gambar 4 di atas, torsi yang bekerja pada objek yang digantung dapat dituliskan dalam persamaan berikut,

$$
\tau=-2\left(\frac{m g}{2}\right) r \sin \phi=-m g r \sin \phi
$$

dengan angka 2 menyatakan bahwa momen pemulih pada kedua ujung objek menghasilkan osilasi pada arah yang sama, sedangkan tanda negatif menunjukkan bahwa gaya pemulih bekerja pada arah yang berlawanan dengan arah gerak objek.

Berdasarkan hukum kedua Newton untuk gerak angular, torsi dari benda yang berputar dinyatakan dalam persamaan sebagai berikut.

$$
\tau=I a=I\left(\frac{d^{2} \theta}{d t^{2}}\right)
$$

Persamaan gerak angular dari bifilar pendulum dapat diturunkan dengan menggunakan persamaan (1) dan (2) di atas. Kendati demikian, persamaan (1) menyatakan gerak angular dalam fungsi $\Phi$, sedangkan Persamaan (2) menyatakan gerak angular dalam fungsi $\theta$. Oleh karena itu, diperlukan persamaan yang dapat menyatakan hubungan antara $\Phi$ dengan $\theta$ terlebih dahulu. Dengan melihat segitiga vertikal pada Gambar 4 di atas, maka dapat diperoleh persamaan berikut.

$$
d=L^{b} \sin \phi \approx L \sin \phi
$$

Karena $\Phi$ bernilai kecil, maka besarnya L' dapat diasumsikan sama dengan L. Kemudian dari segitiga horizontal pada Gambar 4 dapat diperoleh persamaan berikut.

$$
d=r \tan \theta \approx r \sin \theta \approx r \theta
$$

Sama seperti halnya $\Phi$, nilai dari $\theta$ dapat diasumsikan kecil. Kemudian dengan menggunakan persamaan (3) dan (4) di atas, maka dapat diperoleh hubungan antara $\Phi$ dengan $\theta$ sebagai berikut.

$$
\sin \phi \approx\left(\frac{r}{L}\right) \theta
$$

Dengan mensubtitusikan persamaan (5) pada persamaan (1), kemudian memasukkan hasil dari kedua persamaan terebut ke dalam persamaan (2), maka diperoleh persamaan gerak pada bifilar pendulum sebagai berikut.

$$
\frac{d^{2} \theta}{d t^{2}}+\left(\frac{m g r^{2}}{I L}\right) \theta=0
$$

Dari persamaan (6) di atas, nampak bahwa persamaan gerak dari bifilar pendulum memiliki bentuk yang mirip dengan persamaan gerak pada pendulum sederhana. Dengan demikian, dapat diperoleh persamaan untuk kecepatan angular dari bifilar pendulum adalah sebagai berikut.

$$
\omega=\sqrt{\frac{m g r^{2}}{u L}}
$$

Dengan demikian, maka persamaan periode osilasi untuk bifilar pendulum dapat dituliskan sebagai berikut.

$$
T=\frac{2 \pi}{r} \sqrt{\frac{L I}{m g}}
$$

Dengan menggunakan persamaan (8) di atas, maka besarnya momen inersia dari suatu objek dapat diestimasikan jika nilai dari periode osilasi objek tersebut diperoleh melalui uji bifilar pendulum.

\section{Setup dan Prosedur Uji Bifilar Pendulum}

Bifilar pendulum dapat dibuat dengan sederhana, yakni dengan menggantung objek uji pada dua buah tali dengan panjang dan jarak tertentu, sebagaimana yang ditunjukkan pada Gambar 3 di atas. Untuk itu, peralatan uji yang diperlukan antara lain adalah test stand dan dua buah tali. Test stand digunakan untuk menggantung objek, dapat berupa kerangka atau tiang. Jika objek uji sulit digantung dengan menggunakan tali, maka diperlukan sebuah dudukan untuk menggantung objek tersebut.

Untuk uji bifilar pendulum pada laboratorium terbang, test stand dibuat dari kayu. Test stand didesain agar dapat dibongkar-pasang, sehingga 
dapat disimpan pada tempat dengan ukuran terbatas. Panjang dari test stand adalah 1,6 m, dengan tinggi $1,5 \mathrm{~m}$.

Agar laboratorium terbang dapat digantung pada test stand, ia harus dipasangkan terlebih dahulu pada sebuah dudukan. Laboratorium terbang dengan dudukannya digantung dengan menggunakan benang wol.

Untuk memperoleh hasil yang lebih akurat, direkomendasikan untuk menggunakan tali yang lebih pendek [4]. Dengan menggunakan tali yang lebih pendek, momen inersia dari UAV pada sumbunya akan memiliki persentase yang besar dari total momen inersia pendulum pada sumbu osilasinya [9].

Setup uji bifilar pendulum pada laboratorium terbang ditunjukkan oleh gambar berikut.

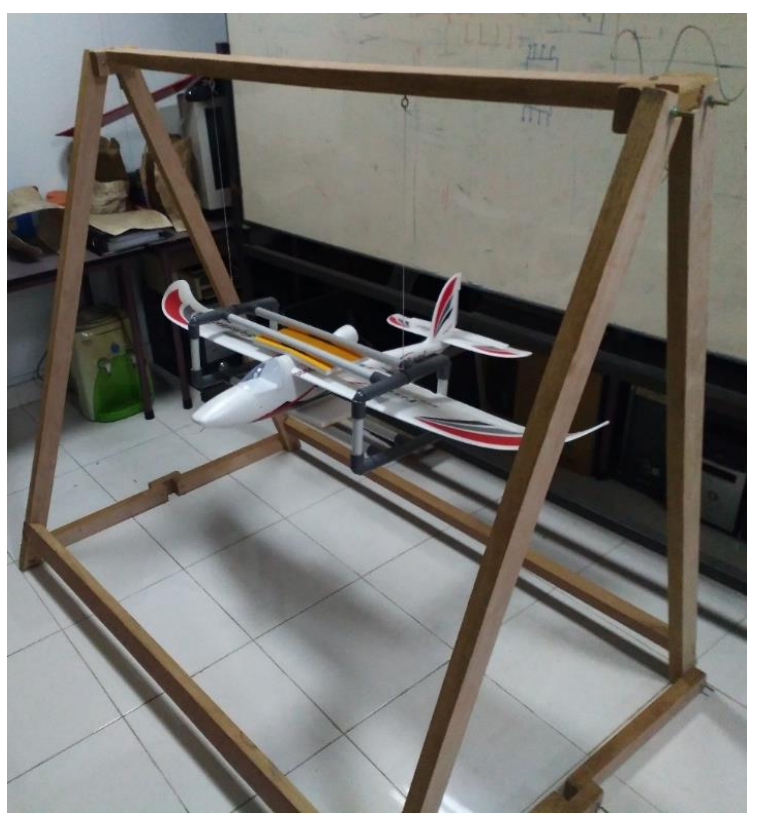

Gambar 5 setup uji bifilar pendulum pada laboratorium terbang

Dengan adanya dudukan yang digunakan untuk menyangga laboratorium terbang, tentunya akan mempengaruhi nilai dari momen inersia yang diperoleh. Oleh karena itu, nantinya perlu dilakukan pengurangan antara hasil momen inersia dari laboratorium terbang dan dudukannya dengan hasil momen inersia dari dudukan kosong.

Uji bifilar pendulum dilakukan dengan
memberikan simpangan dengan memutar
pendulum pada bidang horizontal. Simpangan
yang diberikan tidak boleh terlalu besar karena
perhitungan yang digunakan menggunakan
asumsi simpangan kecil. Kemudian simpangan
dilepaskan dan waktu yang dibutuhkan oleh
pendulum untuk melakukan sejumlah osilasi

tertentu diukur dengan menggunakan stopwatch. Hasil yang diperoleh kemudian digunakan untuk menghitung besarnya periode osilasi dari pendulum. Dari hasil perhitungan periode osilasi tersebut, momen inersia dari laboratorium terbang dapat dihitung dengan menggunakan persamaan 8 di atas.

\section{Validasi Peralatan Uji}

Akurasi dari hasil pengujian sangat bergantung pada konstruksi pendulum, dimensi dan juga kepresisian dari pengukuran [4]. Sebagaimana yang terlihat pada Gambar 5 di atas, konstruksi dari bifilar pendulum dibuat dengan sederhana. Oleh karena itu, perlu dilakukan uji validasi pada peralatan uji untuk melihat apakah hasil momen inersia yang diperoleh dapat mewakili karakteristik yang sebenarnya dari objek.

Uji validasi dilakukan dengan melakukan pengujian pada sebuah balok kayu berukuran kecil. Balok kayu tersebut terbuat dari particle board dengan berat hanya 1,006 kg.

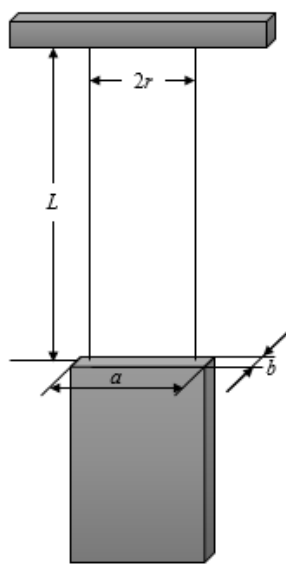

Gambar 6 skema uji bifilar pendulum pada balok kayu

Selain karena mudah diperoleh, besarnya momen inersia dari balok kayu juga mudah untuk dihitung dengan menggunakan metode analitik. Besarnya momen inersia untuk sebuah balok dapat diestimasikan dengan menggunakan persamaan berikut.

$$
I_{\text {Balok }}=\frac{1}{12} m\left(a^{2}+b^{2}\right)
$$

Dengan menggunakan persamaan di atas, untuk lebar dan tebal balok masing-masing sebesar $0,235 \mathrm{~m}$ dan $0,015 \mathrm{~m}$, diperoleh nilai momen inersia sebesar 0,0046 $\mathrm{kg} \mathrm{m}^{2}$. Hasil ini selanjutnya akan dibandingkan dengan hasil uji bifilar pendulum. 
Setup pengujian bifilar pendulum dengan menggunakan balok kayu sebagai objek uji ditunjukkan pada gambar berikut.

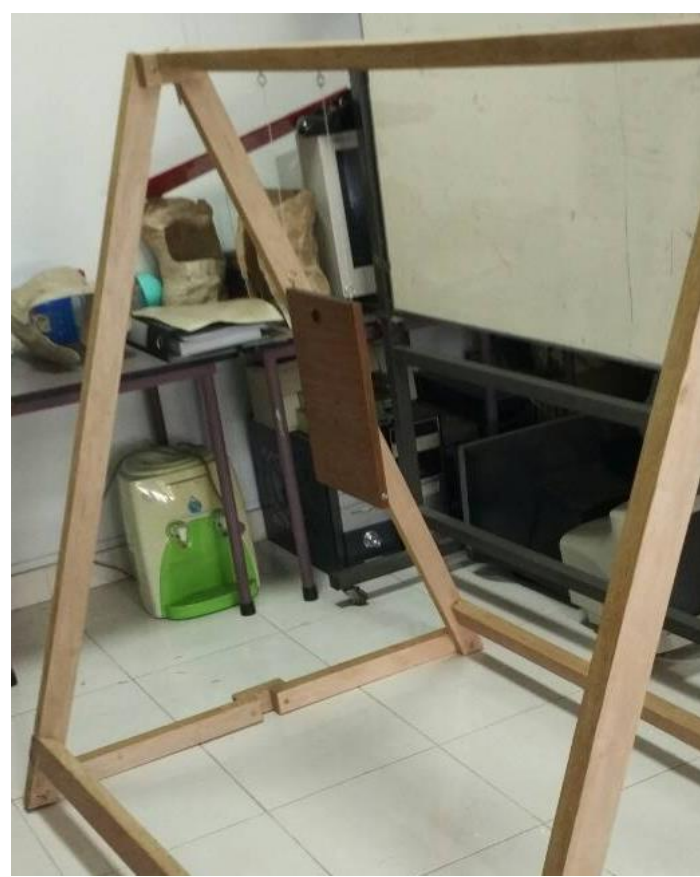

Gambar 7 setup uji validasi dengan balok kayu sebagai objek uji

Balok kayu dipasang pada dua buah tali dengan panjang 0,32 $\mathrm{m}$ dengan jarak antara kedua tali adalah 0,2 m. Hasil uji validasi ditunjukkan pada tabel berikut.

Tabel 1 Hasil uji validasi dengan menggunakan balok kayu

\begin{tabular}{|l|l|l|l|}
\hline $\begin{array}{c}\text { jumlah } \\
\text { osilasi }\end{array}$ & $\begin{array}{c}\text { waktu } \\
\text { untuk } \\
\text { osilasi } \\
(\mathrm{s})\end{array}$ & $\begin{array}{c}\text { periode } \\
(\mathrm{s})\end{array}$ & $\begin{array}{c}\text { momen } \\
\text { inersia } \\
\left(\mathrm{kg} \mathrm{m}^{2}\right)\end{array}$ \\
\hline 10 & 8,2 & 0,82 & 0,0053 \\
\hline 10 & 8,2 & 0,82 & 0,0053 \\
\hline 10 & 8,1 & 0,82 & 0,0051 \\
\hline 15 & 12,1 & 0,81 & 0,0051 \\
\hline 15 & 12,1 & 0,81 & 0,0051 \\
\hline 15 & 12,2 & 0,81 & 0,0052 \\
\hline 20 & 16 & 0,8 & 0,0050 \\
\hline 20 & 16,1 & 0,81 & 0,0050 \\
\hline 20 & 16 & 0,8 & 0,0051 \\
\hline rata-rata & & & 0,0051 \\
\hline
\end{tabular}

Berdasarkan hasil uji bifilar pendulum, diperoleh nilai momen inersia sebesar $0,0051 \mathrm{~kg} \mathrm{~m}^{2}$. Jika melihat hasil dari kedua metode, diperoleh perbedaan hasil sebesar $0,0005 \mathrm{~kg} \mathrm{~m}^{2}$. Error yang diperoleh sebenarnya cukup signifikan, yakni $10,87 \%$. Kendati demikian, selain diakibatkan oleh adanya ketidakpastian dalam pengukuran dan konstruksi pendulum, error juga dapat disebabkan oleh ketidakhomogenan material dari balok kayu itu sendiri. Balok kayu terbuat dari particle board yang tersusun dari serbuk gergaji, potongan kayu kecil, serpihan kayu, dan bahan kimia resin yang dipadatkan dengan tekanan tinggi lalu kemudian dikeringkan. Particle board dapat memiliki poripori yang cukup besar. Oleh karena itu, besar kemungkinan material penyusun balok kayu tidak bersifat homogen. Dengan demikian, hasil uji dari bifilar pendulum masih dapat diterima dan digunakan untuk memodelkan momen inersia dari laboratorium terbang.

\section{Uji Bifilar Pendulum pada Model Laboratorium Terbang}

Uji bifilar pendulum pada laboratorium terbang dilakukan dalam tiga bagian, yakni uji momen inersia roll $\left(I_{x x}\right)$, momen inersia pitch $\left(l_{y y}\right)$, dan momen inersia yaw $\left(\mathrm{I}_{\mathrm{zz}}\right)$.

\subsection{Uji momen inersia roll}

Untuk uji momen inersia roll, laboratorium terbang dipasang pada test stand dengan posisi sebagaimana yang ditunjukkan pada Gambar 7 . Sumbu $\mathrm{x}$ benda dipasang secara vertikal, sejajar dengan tali.

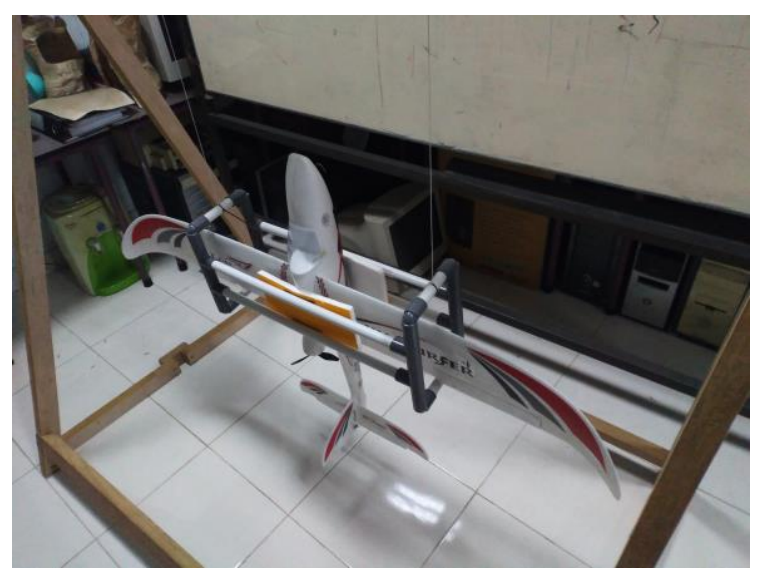

Gambar 8 setup uji momen inersia roll untuk laboratorium terbang dan dudukan

Karena pengujian pada laboratorium terbang melibatkan dudukan, maka perlu dipastikan bahwa lokasi dari titk pusat massa dari dudukan yang kosong dan dudukan yang telah memuat laboratorium terbang berada pada sumbu rotasi yang sama dengan bidang yang dibentuk oleh tali. 
Berikut adalah pemasangan dudukan kosong untuk uji momen inersia roll.

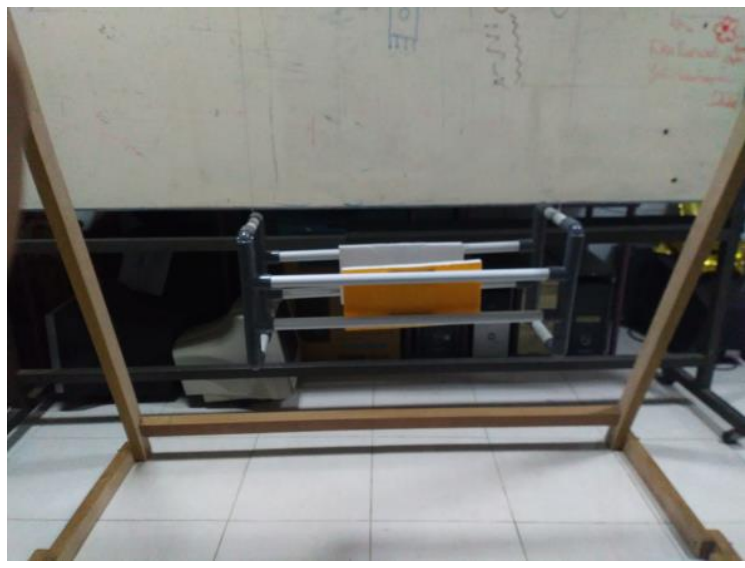

Gambar 9 setup uji momen inersia roll untuk dudukan kosong

Rincian setup untuk uji momen inersia roll ditunjukkan pada tabel berikut ini.

Tabel 2 Rincian setup uji momen inersia roll

\begin{tabular}{|l|l|}
\hline \multicolumn{1}{|c|}{ properti } & \multicolumn{1}{c|}{ nilai } \\
\hline massa dudukan $(\mathrm{kg})$ & 1,218 \\
\hline panjang tali $(\mathrm{m})$ & 0,5 \\
\hline jarak antara dua tali $(\mathrm{m})$ & 0,61 \\
\hline
\end{tabular}

Hasil uji momen inersia roll untuk ditunjukkan pada tabel-tabel berikut.

Tabel 3 Hasil uji momen inersia roll untuk laboratorium terbang dan dudukan

\begin{tabular}{|l|l|l|l|}
\hline $\begin{array}{c}\text { jumlah } \\
\text { osilasi }\end{array}$ & $\begin{array}{c}\text { waktu } \\
\text { untuk } \\
\text { osilasi } \\
(\mathrm{s})\end{array}$ & \multicolumn{1}{|c|}{$\begin{array}{c}\text { periode } \\
(\mathrm{s})\end{array}$} & $\begin{array}{c}\text { momen } \\
\text { inersia } \\
\left(\mathrm{kg} \mathrm{m}^{2}\right)\end{array}$ \\
\hline 3 & 3,5 & 1,17 & 0,1227 \\
\hline 3 & 3,7 & 1,23 & 0,1371 \\
\hline 3 & 3,5 & 1,17 & 0,1227 \\
\hline 5 & 5,8 & 1,16 & 0,1213 \\
\hline 5 & 6,1 & 1,22 & 0,1342 \\
\hline 5 & 5,9 & 1,18 & 0,1255 \\
\hline 7 & 8,2 & 1,17 & 0,1237 \\
\hline 7 & 8,3 & 1,19 & 0,1267 \\
\hline 7 & 8,1 & 1,16 & 0,1207 \\
\hline rata-rata & & & 0,1261 \\
\hline
\end{tabular}

Tabel 4 Hasil uji momen inersia roll untuk dudukan kosong

\begin{tabular}{|l|l|l|l|}
\hline $\begin{array}{c}\text { jumlah } \\
\text { osilasi }\end{array}$ & $\begin{array}{c}\text { waktu } \\
\text { untuk } \\
\text { osilasi } \\
(\mathrm{s})\end{array}$ & \multicolumn{1}{|c|}{$\begin{array}{c}\text { periode } \\
(\mathrm{s})\end{array}$} & $\begin{array}{c}\text { momen } \\
\text { inersia } \\
\left(\mathrm{kg} \mathrm{m}^{2}\right)\end{array}$ \\
\hline 5 & 6,8 & 1,36 & 0,1043 \\
\hline 5 & 6,5 & 1,3 & 0,0953 \\
\hline 5 & 6,7 & 1,34 & 0,1012 \\
\hline 10 & 13,4 & 1,34 & 0,1012 \\
\hline 10 & 13,6 & 1,36 & 0,1043 \\
\hline 10 & 13,3 & 1,33 & 0,0997 \\
\hline 15 & 19,9 & 1,33 & 0,0992 \\
\hline 15 & 20,1 & 1,34 & 0,1012 \\
\hline 15 & 19,9 & 1,33 & 0,0992 \\
\hline rata-rata & & & 0,1006 \\
\hline
\end{tabular}

Dengan mengurangkan hasil uji dari laboratorium terbang dan dudukan dengan hasil uji dari dudukan kosong, maka diperoleh nilai dari momen inersia roll laboratorium terbang adalah sebesar $0,0255 \mathrm{~kg} \mathrm{~m}^{2}$.

\subsection{Uji momen inersia pitch}

Uji momen inersia pitch dilakukan dengan memasang laboratorium terbang dan dudukan pada test stand sebagai berikut.

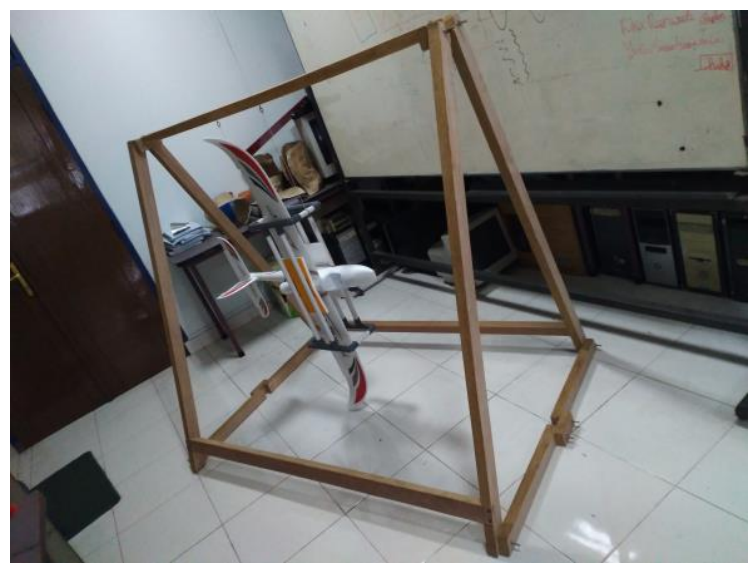

Gambar 10 setup uji momen inersia pitch untuk laboratorium terbang dan dudukan

Karena test stand tidak terlalu tinggi, maka panjang tali harus diatur sedemikian rupa agar sayap dari laboratorium terbang tidak bergesekan dengan tiang penyangga ataupun lantai. Untuk pemasangan dudukan kosong pada test stand ditunjukkan pada gambar berikut. 
Seminar Nasional Instrumentasi, Kontrol dan Otomasi (SNIKO) 2018 Bandung, Indonesia, 10-11 Desember 2018

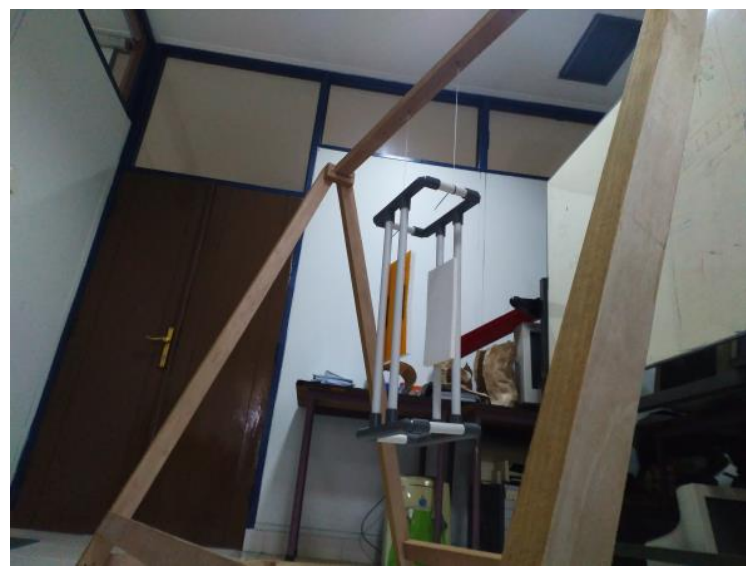

Gambar 11 setup uji momen inersia pitch untuk dudukan kosong

Rincian setup pada uji momen inersia pitch ditunjukkan pada tabel berikut.

Tabel 5 Rincian setup uji momen inersia pitch

\begin{tabular}{|l|l|}
\hline \multicolumn{1}{|c|}{ properti } & \multicolumn{1}{c|}{ nilai } \\
\hline massa dudukan $(\mathrm{kg})$ & 1,218 \\
\hline panjang tali $(\mathrm{m})$ & 0,38 \\
\hline jarak antara dua tali $(\mathrm{m})$ & 0,26 \\
\hline
\end{tabular}

Diperoleh hasil uji momen inersia pitch sebagai berikut.

Tabel 6 Hasil uji momen inersia pitch untuk laboratorium terbang dan dudukan

\begin{tabular}{|l|l|l|l|}
\hline $\begin{array}{c}\text { jumlah } \\
\text { osilasi }\end{array}$ & $\begin{array}{c}\text { waktu } \\
\text { untuk } \\
\text { osilasi } \\
(\mathrm{s})\end{array}$ & $\begin{array}{c}\text { periode } \\
(\mathrm{s})\end{array}$ & $\begin{array}{c}\text { momen } \\
\text { inersia } \\
\left(\mathrm{kg} \mathrm{m}^{2}\right)\end{array}$ \\
\hline 3 & 4 & 1,33 & 0,0383 \\
\hline 3 & 3,7 & 1,23 & 0,0328 \\
\hline 3 & 3,8 & 1,27 & 0,0346 \\
\hline 5 & 6,7 & 1,34 & 0,0387 \\
\hline 5 & 6,7 & 1,34 & 0,0387 \\
\hline 5 & 6,5 & 1,3 & 0,0364 \\
\hline 7 & 9,5 & 1,36 & 0,0397 \\
\hline 7 & 9,5 & 1,36 & 0,0397 \\
\hline 7 & 9,4 & 1,34 & 0,0389 \\
\hline rata-rata & \multicolumn{3}{|l}{} \\
\hline
\end{tabular}

Tabel 7 Hasil uji momen inersia pitch untuk dudukan kosong

\begin{tabular}{|l|l|l|l|}
\hline $\begin{array}{c}\text { jumlah } \\
\text { osilasi }\end{array}$ & $\begin{array}{c}\text { waktu } \\
\text { untuk } \\
\text { osilasi } \\
(\mathrm{s})\end{array}$ & \multicolumn{1}{|c|}{$\begin{array}{c}\text { periode } \\
(\mathrm{s})\end{array}$} & $\begin{array}{c}\text { momen } \\
\text { inersia } \\
\left(\mathrm{kg} \mathrm{m}^{2}\right)\end{array}$ \\
\hline 5 & 6,1 & 1,22 & 0,0201 \\
\hline 5 & 5,7 & 1,14 & 0,0175 \\
\hline 5 & 5,8 & 1,16 & 0,0181 \\
\hline 10 & 11,5 & 1,15 & 0,0178 \\
\hline 10 & 11,3 & 1,13 & 0,0172 \\
\hline 10 & 11,3 & 1,13 & 0,0172 \\
\hline 15 & 17 & 1,13 & 0,0173 \\
\hline 15 & 17,1 & 1,14 & 0,0175 \\
\hline 15 & 17 & 1,13 & 0,0173 \\
\hline rata-rata & & & 0,0178 \\
\hline
\end{tabular}

Berdasarkan hasil di atas, diperoleh momen inersia pitch dari model laboratorium terbang adalah sebesar 0,0197 $\mathrm{kg} \mathrm{m}^{2}$.

\subsection{Uji momen inersia yaw}

Untuk uji momen inersia yaw, pemasangan laboratorium terbang dan dudukan pada test stand dapat dilihat pada Gambar 5 di atas. Untuk pemasangan dudukan kosong pada test stand adalah sebagai berikut.

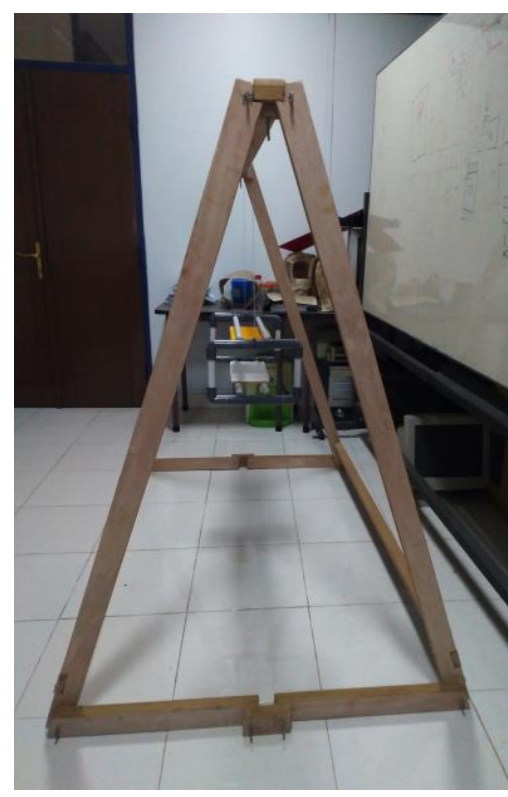

Gambar 12 setup uji momen inersia yaw untuk dudukan kosong 
Tabel 8 Rincian setup uji momen inersia yaw

\begin{tabular}{|l|l|}
\hline \multicolumn{1}{|c|}{ properti } & \multicolumn{1}{c|}{ nilai } \\
\hline massa dudukan $(\mathrm{kg})$ & 1,218 \\
\hline panjang tali $(\mathrm{m})$ & 0,5 \\
\hline jarak antara dua tali $(\mathrm{m})$ & 0,61 \\
\hline
\end{tabular}

Berikut adalah data hasil pengujian bifilar pendulum untuk pemodelan momen inersia yaw.

Tabel 9 Hasil uji momen inersia yaw untuk laboratorium terbang dan dudukan

\begin{tabular}{|l|l|l|l|}
\hline $\begin{array}{c}\text { jumlah } \\
\text { osilasi }\end{array}$ & $\begin{array}{c}\text { waktu } \\
\text { untuk } \\
\text { osilasi } \\
(\mathrm{s})\end{array}$ & $\begin{array}{c}\text { periode } \\
(\mathrm{s})\end{array}$ & $\begin{array}{c}\text { momen } \\
\text { inersia } \\
\left(\mathrm{kg} \mathrm{m}^{2}\right)\end{array}$ \\
\hline 5 & 6,3 & 1,26 & 0,1431 \\
\hline 5 & 6,5 & 1,3 & 0,1524 \\
\hline 5 & 6,4 & 1,28 & 0,1477 \\
\hline 10 & 13 & 1,3 & 0,1524 \\
\hline 10 & 12,9 & 1,29 & 0,15 \\
\hline 10 & 12,9 & 1,29 & 0,15 \\
\hline 15 & 19,5 & 1,3 & 0,1524 \\
\hline 15 & 19,3 & 1,29 & 0,1492 \\
\hline 15 & 19,4 & 1,29 & 0,1508 \\
\hline rata-rata & & & 0,1498 \\
\hline
\end{tabular}

Tabel 10 Hasil uji momen inersia yaw untuk dudukan kosong

\begin{tabular}{|l|l|l|l|}
\hline $\begin{array}{c}\text { jumlah } \\
\text { osilasi }\end{array}$ & $\begin{array}{c}\text { waktu } \\
\text { untuk } \\
\text { osilasi } \\
(\mathrm{s})\end{array}$ & $\begin{array}{c}\text { periode } \\
(\mathrm{s})\end{array}$ & $\begin{array}{c}\text { momen } \\
\text { inersia } \\
\left(\mathrm{kg} \mathrm{m}^{2}\right)\end{array}$ \\
\hline 5 & 6,5 & 4,83 & 0,0953 \\
\hline 5 & 6,5 & 4,83 & 0,0953 \\
\hline 5 & 6,6 & 4,76 & 0,0982 \\
\hline 10 & 13,3 & 4,72 & 0,0997 \\
\hline 10 & 13,2 & 4,76 & 0,0982 \\
\hline 10 & 13,2 & 4,79 & 0,0967 \\
\hline 15 & 19,5 & 4,83 & 0,0953 \\
\hline 15 & 19,7 & 4,78 & 0,0972 \\
\hline 15 & 19,8 & 4,76 & 0,0982 \\
\hline rata-rata & & & 0,0971 \\
\hline
\end{tabular}

Berdasarkan hasil di atas, diperoleh momen inersia yaw untuk model laboratorium terbang adalah $0,0527 \mathrm{~kg} \mathrm{~m}^{2}$.

\section{Diskusi dan Analisis}

Dari seluruh pengujian yang dilakukan, diperoleh hasil momen inersia laboratorium terbang sebagai berikut.

Tabel 11 Momen inersia laboratorium terbang hasil uj bifilar pendulum

\begin{tabular}{|l|c|}
\hline \multicolumn{1}{|c|}{ properti } & nilai \\
\hline momen inersia roll $\left(I_{x x}\right)$ & $0,0255 \mathrm{~kg} \mathrm{~m}^{2}$ \\
\hline momen inersia pitchl $\left(l_{y y}\right)$ & $0,0197 \mathrm{~kg} \mathrm{~m}^{2}$ \\
\hline momen inersia yaw $\left(\mathrm{I}_{z z}\right)$ & $0,0527 \mathrm{~kg} \mathrm{~m}^{2}$ \\
\hline
\end{tabular}

Hasil momen inersia yang diperoleh menunjukkan nilai yang relatif wajar untuk pesawat nirawak bersayap tetap sekelasnya. Sebagai pembanding, berikut ditampilkan momen inersia dari pesawat nirawak Ultrasick 25 e yang memiliki berat take off 2,15 kg dengan panjang sayap 1,27 m.

Tabel 12 Momen inersia pesawat nirawak Ultrasick 25e

\begin{tabular}{|l|c|}
\hline \multicolumn{1}{|c|}{ properti } & nilai \\
\hline momen inersia roll $\left(\mathrm{I}_{\mathrm{xx}}\right)$ & $0,07151 \mathrm{~kg} \mathrm{~m}^{2}$ \\
\hline momen inersia pitchl $\left(\mathrm{l}_{\mathrm{yy}}\right)$ & $0,08636 \mathrm{~kg} \mathrm{~m}^{2}$ \\
\hline momen inersia yaw $\left(\mathrm{I}_{\mathrm{zz}}\right)$ & $0,15364 \mathrm{~kg} \mathrm{~m}^{2}$ \\
\hline
\end{tabular}

Dari kedua tabel di atas, nampak bahwa secara umum nilai momen inersia dari pesawat nirawak Ultrasick 25e sekitar tiga kali lebih besar dibandingkan nilai momen inersia dari laboratorium terbang. Hal ini cukup logis, mengingat massa dari Ultrasick 25e tiga kali lipat lebih besar dari massa laboratorium terbang.

Momen inersia yaw dari kedua pesawat menunjukkan nilai yang terbesar, yakni sekitar dua kali nilai momen inersia roll. Hal tersebut menunjukkan bahwa baik laboratorium terbang maupun Ultrasick 25e memiliki tendensi untuk menolak percepatan angular yawing lebih besar dibandingkan rolling dan pitching. Hal ini disebabkan oleh distribusi massa yang besar pada arah sumbu $x$ dan sumbu y benda dengan adanya sayap dan fuselage. 


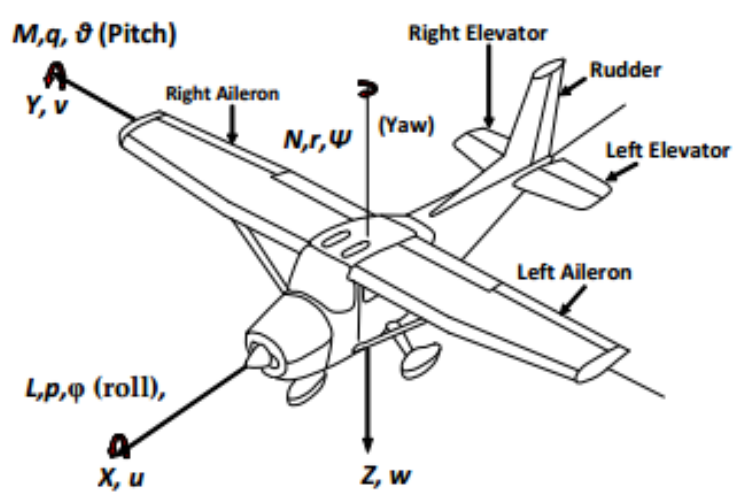

Gambar 13 ilustrasi pesawat nirawak Ultrasick 25e [10]

Terdapat perbedaan karakteristik pada nilai momen inersia roll dan pitch dari kedua pesawat. Nilai momen inersia roll dari laboratorium terbang sedikit lebih besar dibandingkan nilai momen inersia pitch-nya. Hal ini disebabkan laboratorium terbang memiliki ukuran sayap yang lebih dominan dibandingkan ukuran badannya. Sebaliknya, Ultrasick 25e memiliki nilai momen inersia pitch yang sedikit lebih besar dibandingkan nilai momen inersia roll-nya. Hal ini dikarenakan Ultrasick 25e memiliki ukuran badan yang relatif besar jika dibandingkan komponen lainnya, sebagaimana yang ditunjukkan pada gambar 13 di atas. Secara umum, karakteristik momen inersia laboratorium terbang sudah mirip dengan pesawat nirawak bersayap tetap sekelasnya.

\section{Kesimpulan}

Pada makalah ini telah dilakukan uji bifilar pendulum untuk memodelkan momen inersia dari laboratorium terbang. Bifilar pendulum dibuat dengan sederhana, terdiri dari kerangka kayu, tali, dan dudukan. Hasil uji menunjukkan nilai yang relatif wajar untuk pesawat nirawak bersayap tetap sekelasnya. Momen inersia yaw dari laboratorium terbang memiliki nilai yang paling besar, disusul dengan momen inersia roll dan momen inersia pitch. Hal ini disebabkan oleh ukuran sayap dari laboratorium terbang yang dominan dibandingkan ukuran fuselage.

\section{Ucapan Terima Kasih}

Terima kasih disampaikan pada Kementerian Riset, Teknologi, dan Pendidikan Tinggi (Kemenristekdikti) atas pendaan untuk riset ini.

\section{Nomenklatur}

$$
\mathrm{T}=\text { torsi }
$$

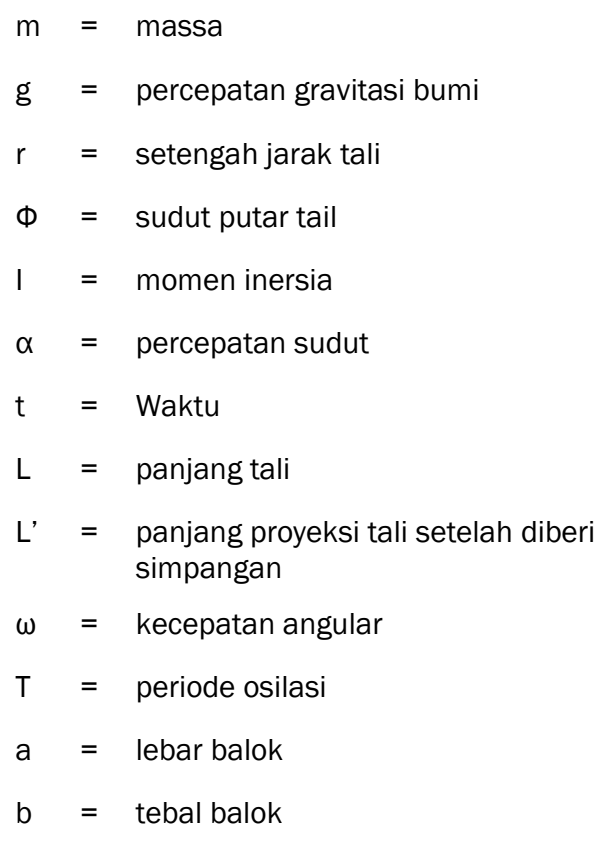

\section{Daftar Pustaka}

[1] O. Arifianto, H. Muhammad, P. S. Windratih, and I. Safi'i, "The development of student station for drag polar testing," International Conference on Aviation Technology and Management (ICATEM), September 2018.

[2] P. S. Windratih, O. Arifianto, and $\mathrm{H}$. Muhammad, "The development of flight testing tool for longitudinal static stability assessment," International Conference on Science and Innovative engineering (ICSIE), December 2017.

[3] P. S. Windratih, Pengembangan student station dalam rangka pengujian longitudinal static stability dari pesawat tanpa awak bersayap tetap. Undergraduate thesis, Institut Teknologi Bandung, April 2017.

[4] A. Teimourian and D. Firouzbakht, "A practical method for determination of the moments of inertia of unmanned aerial vehicles," Italian Association of Aeronautic and Astronautics XXII Conference, September 2013.

[5] E. C. Harris, "Selection of techniques for measurement of moment of inertia," 24th Annual Conference S.A.W.E., May 1965.

[6] G. Genta and C. Delprete, "Some considerations on the experimental determination of moments of inertia," Meccanica, vol 29, pp. 125-141, 1994.

[7] M. R. Jardin, “Optimized measurements of UAV mass moment of inertia with a bifilar pendulum," Journal of Aircraft, May 2009.

[8] A. Shaheen and M. S. Anwar, A Doubly Suspended Pendulum. LUMS School of Science and Engineering, May 2017. 
[9] M. P. Miller, "An accurate method of measurement the moment of inertia of airplanes," National Advisory Committee for Aeronautics, Technical note No.351, October 1930
[10]B. K. Aliyu, A. A. Petinrin, \& J. A. Adewumi, “PID control design of sideslip angle for fixed-wing mini-UAV," Advances in Research. Vol. 6, pp. 114,2016 